\title{
COMMENTS
}

\section{Comparative Negligence, Multiple Parties, and Settlements}

In $L i$ v. Yellow Cab Company, ${ }^{1}$ California joined the growing number of jurisdictions that have abandoned the coinunon law doctrine of contributory negligence in favor of comparative negligence. ${ }^{2}$ Both because the reform was adopted judicially and because of the rationale of the opinion, the $L i$ decision has spurred a reexamination of other elements of the existing system of tort liability. Most courts and commentators have focused their attention on the adoption of rules of contribution and joinder that would pernit allocation of liability among tortfeasors in proportion to their fault. ${ }^{3}$ In the recent case of American Motorcycle Association v. Superior Court, for example, a California Court of Appeal held that the rationale of $L i$ required the abrogation of the common law doctrine of joint and several liability and adoption of a system of proportional liability among defendants. ${ }^{4}$ As with most of the comment in this area, however, the court failed to extend its analysis to the closely related area of settlements, in spite of the fact that the vast majority of all tort clains are settled ${ }^{5}$ and that current

1. 13 Cal. 3d 804, 532 P.2d 1226, 119 Cal. Rptr. 858 (1975).

2. Prior to 1969 , only a handful of American jurisdictions had adopted comparative negligence rules. Since that time, over a score of American states have done so. For a list of these jurisdictions, see Fleming, Foreword: Comparative Negligence at Last-By Judicial Choice, 64 CALIF. L. Rev. 239, 240 (1976) [hereinafter cited as Fleming].

3. American Motorcycle Ass'n v. Superior Court, 65 Cal. App. 3d 694, 135 Cal. Rptr. 497 (2d Dist. 1977), hearing granted, No. L.A. 30737 (Cal. Sup. Ct. Feb. 11, 1977). Contra, Safeway Stores, Inc. v. Nest-Kart, 63 Cal. App. 3d 934, 134 Cal. Rptr. 150 (1st Dist. 1976), hearing granted, No. S.F. 23596 (Cal. Sup. Ct. Feb. 11, 1977). See generally Braun, Contribution: A Fresh Look, 50 CAL. ST. B.J. 166 (1975); Goldenberg \& Nicholas, Comparative Liability Among Joint Tortfeasors: The Aftermath of Li v. Yellow Cab Co., 8 U.W.L.A. L. Rev. 23 (1976); Schwartz, Li v. Yellow Cab Co.: A Survey of California Practice Under Comparative Negligence, 7 PAc. L.J. 747 (1976).

4. 65 Cal. App. 3d 694, 704, 135 Cal. Rptr. 497, 503 (2d Dist. 1977), hearing granted, No. L.A. 30737 (Cal. Sup. Ct. Feb. 11, 1977).

5. Professor Fleming notes that the current tendency is for most claims to be settled by negotiation rather than in court. Fleming, supra note 2, at 247. Professor James indicated that, even in 1941, over $90 \%$ of all claims were settled before judg- 
settlement rules are sharply at variance with the principles announced in $L i$, in that they can cause significant fluctuations in liability that are unrelated to the fault of the parties involved. ${ }^{b}$

This Comment scrutinizes the law governing the liability of joint tortfeasors in light of the principles set forth in $\mathbf{L i}$. Part I presents the existing rules of contribution and settlement among joint tortfeasors. Part II discusses the $L i$ decision and outlines the manner in which American Motorcycle Association has extended $L i$ 's rationale to the area of joinder and contribution. Part III demonstrates the incompatibility of existing settlement rules with the $L i$ decision and explores the consequences of reforms that allow liability to be apportioned among all tortfeasors in relation to fault. Finally, Part IV indicates how the proposed changes can be adopted by judicial action and demonstrates why the proposed reforins should be accomplished by the courts rather than by the legislature.

\section{I}

\section{Contribution and Settlement Among}

\section{JOINT TORTFEASORS}

When one suffers a single, physically indivisible injury as the result of acts of independent tortfeasors, common sense would appear to dictate that liability for damages be apportioned between the tortfeasors in proportion to their respective degrees of responsibility. The common law, lowever, is to the contrary; traditionally, each tortfeasor has been held individually liable for the entire indivisible injury. ${ }^{7}$ The practical justification most often advanced to support this rule is that, since the injury is not capable of any "logical, reasonable or practical division," admimistrative convemience demands that each tortfeasor be held entirely liable. ${ }^{8}$ More fundamentally, the rule represents a choice that, in situations where one or more of the joint tortfeasors would be unable to contribute a "fair share" of the plaintiff's damages, the bur-

ment. James, Contribution Among Joint Tortfeasors: A Pragmatic Criticism, 54 HARv. L. REV. 1156, 1160 n.12 (1941).

6. See illustration at note 64 infra.

7. Fleming, supra note 2, at 251.

8. W. PROSSER, LAW OF TORTS 315 (4th ed. 1971) [hereinafter cited as Prosser]. Dean Prosser states that "entire liability rests upon the obvious fact that each [tortfeasor] has contributed to the single result, and that no rational division can be made." Id. at 316. Professor Gregory has labeled joint and several liability an "administrative tour de force enabling the courts to sidestep the difficult task of allocating relative degrees of fault among two or more tortfeasors . . . " Gregory, Contribution Among Joint Tortfeasors: A Defense, 54 HARv. L. REV. 1170 (1941). 
den should be borne by the other tortfeasors rather than by an innocent plaintiff. ${ }^{\ominus}$

For a tortfeasor who is only partially responsible for plaintiff's injuries, imposition of entire liability may have harsh consequences. ${ }^{10}$ The inequities of the coinmon law rule, however, have been tempered by several inportant limitations. First, the doctrine of "one satisfaction" prohibits a plaintiff froin recovering more than one judgment for damages caused by joint tortfeasors. ${ }^{11}$ When all defendants are joined in the same action, the likelihood that entire liability will fall to a single tortfeasor has been further reduced by the establishment of a statutory right of contribution. ${ }^{12}$ Contribution statutes typically provide that if the plaintiff has satisfied the judgment against fewer than all defendants, any defendant who has paid inore than a pro rata share of the judgment is entitled to recover the overpayment from the remaining defendants. ${ }^{13}$ This pro rata share is usually deterınined by dividing the amount of judgment by the number of judgment defendants. ${ }^{14}$

9. Discussions of joint and several liability are replete with refercnces to the imbalance in the equities between "innocent" plaintiffs and wrongdoing tortfeasors. See, e.g., Finnegan v. Royal Realty Co., 35 Cal. 2d 409, 434, 218 P.2d 17, 32-33 (1950); Thornton v. Luce, 209 Cal. App. 2d 542, 552, 26 Cal. Rptr. 393, 399 (2d Dist. 1962). See also Fleming, supra note 2, at 251 .

10. Under the rationale of joint and several liability, there is no bar to imposing the entire burden of the plaintiff's loss on a tortfeasor who may only be $5 \%$ at fault in causing those injuries. For a description of some of the abuscs that arise from operation of the doctriue, see Comment, Settlement in Joint Tort Cases, 18 STaN. L. Rev. 486 (1966).

Even assuming that imposition of entire liability is justified in order to protect innocent plaintiffs from the burdens of insolvent or unknown tortfeasors, the remedy has a much broader impact. When coupled with the prohibition against joinder by defendants of uusued tortfeasors, imposition of entire liability allows plaintiffs to recover from defendants damages that may be attributable to cotortfeasors who happen to be friends or relatives of the plaintiff. See notes 15-18 infra and accompanying text.

11. See Prosser, supra note 8, at 299.

12. The forerunner of many of these contribution statutes was the 1939 Uniform Contribution Among Tortfeasors Act.

13. E.g., Cal. Civ. Proc. Code $\S 875$ (West Supp. 1977):

(a) Where a money judgment has been rendered jointly against two or more defendants in a tort action there shall be a right of contribution among them as hereinafter provided.

(b) Such right of contribution shall be administered in accordance with the principles of equity.

(c) Such right of contribution may be enforced only after one tortfeasor has, by payment, discharged the joint judgment or has paid more than his pro rata share thereof. It shall be limited to the excess so paid over the pro rata share of the person so paying and in no event shall any tortfeasor be compelled to make contribution beyond his own pro rata share of the entire judgment. ... .

(g) This title shall not impair the right of a plaintiff to satisfy a judgment in full as against any tortfeasor judgment debtor.

14. Cal. Civ. Proc. Code $\$ 876$ (West Supp. 1977) provides that:

(a) The pro rata share of each tortfeasor judginent debtor shall be deter- 
Despite these important reforms, unfairness remains. California's contribution statute, like those in many other states, limits contribution to those defendants who have actually been sued by the plaintiff. ${ }^{15}$ Such provisions deny defendants the right to contribution froin tortfeasors who have settled ${ }^{16}$ or the right to gain contribution by joining cotortfeasors who are not sued by the plaintiff. ${ }^{17}$ Therefore, if the plaintiff, for personal reasons or otherwise, chooses not to press a claim against one or more tortfeasors, the remaining defendants may be forced to absorb the absent wrongdoer's share of liability. When the tortfeasor is not a party to the litigation because the plaintiff has chosen to settle out of court, current settlement law implements the doctrine of one satisfaction by requiring that any subsequent judgment against cotortfeasors be reduced pro tanto by the dollar amount of the settlement.18 In theory, the defendant is protected from collusive settlements by the further requirement that such settlements be entered into in "good

mined by dividing the entire judgment equally among all of them.

(b) Where one or more persons are held liable solely for the tort of one of them or of another, as in the case of the liability of a master for the tort of his servant, they shall contribute a single pro rata share, as to which there may be indemnity between them.

It is common for such statutes to have a provision indicating that the right of contribution shall be administered in accordance with the "principles of equity." See, e.g., CaL. CIv. Proc. Code $\$ 875$ (b) (West Supp. 1977). These provisions, modeled after the 1955 Uniform Contribution Among Tortfeasors Act, are designed to give courts the opportunity to determine pro rata shares by first excluding insolvent tortfeasors where appropriate. UNIFORM CONTRIBUTION AMONG TorTFEAsors ACT \$2, Coinment (1955).

15. California limits contribution to situations where "a money judgment has been rendered jointly against two or more defendants in a tort action." Cal. Civ. Proc. CoDe $\$ 875$ (a) (West Supp. 1977). For a discussion of the effect of this limitation, see Comment, Joint Tortfeasors: Legislative Changes in the Rules Regarding Releases and Contribution, 9 HAst. L.J. 180 (1958).

16. Cal. Civ. Proc. Code $\$ 877$ (West Supp. 1977) provides that:

Where a release, dismissal with or without prejudice, or a covenant not to sue or not to enforce judgment is given in good faith before verdict or judgment to one or more of a number of tortfeasors clained to be liable for the same tort-

(a) It shall not discharge any other such tortfeasor from liability unless its terms so provide, but it shall reduce the claims against the others in the anount stipulated by the release, the dismissal or the covenant, or in the amount of the consideration paid for it whichever is the greater; and

(b) It shall discharge the tortfeasor to whom it is given from all liability for any contribution to any other tortfeasors.

17. While California joinder rules might be interpreted so as to permit joinder of cotortfeasors, California courts have refused to accept such interpretations. See, e.g., General Electric Co. v. State ex rel. Dep't of Pub. Works, 32 Cal. App. 3d 918, 108 Cal. Rptr. 543 ('1st Dist. 1973). For a discussion of the problems of joinder, see generally Goldenberg \& Nicholas, supra note 3, at 43-54 (1976).

18. Laurenzi v. Vranizan, 25 Cal. 2d 806, 813, 155 P.2d 633, 637 (1945); Burke v. W.R. Chamberlin \& Co., 51 Cal. App. 2d 419, 428, 125 P.2d 120, 125 (2d Dist. 1942). 
faith"-that is, that the consideration for the settlement generally approximates the plaintiff's best estimate of the settled tortfeasor's share of liability ${ }^{19}$ Because of the practical difficulty of enforcing the good faith requirement, ${ }^{20}$ however, the defendant must frequently bear the burden of an intentionally low settlement. ${ }^{21}$

In addition to its role in enforcing the doctrine of one satisfaction, the pro tanto reduction rule also advances other policies. The pro tanto rule embodies the fundamental policies of joint and several liability in that it is easy to administer and it places the burden of any loss resulting from settlements on the tortfeasors rather than on the innocent plaintiff. ${ }^{22}$ Since there is less risk of loss, the rule encourages the plaintiff to settle and advances the strong policies in favor of settleinent. ${ }^{23}$ It is clear, however, that, as with the pro rata contribution rule and the prohibition of joinder by defendants, the pro tanto rule shows no concern for achieving allocation of liability in proportion to fault. If greater emphasis is given to this principle in the future, strikingly different results may occur in this area of the law.

19. See generally River Garden Farms, Inc. v. Superior Court, 26 Cal. App. 3d 986, 996, 103 Cal. Rptr. 498, 505 (3d Dist. 1972). See also Lareau v. Southern Pac. Transp. Co., 44 Cal. App. 3d 783, 792-99, 118 Cal. Rptr. 837, 842-47 (1st Dist. 1975).

There may be situations where a tortfeasor's limited ability to pay his share would justify a settlement for less than the tortfeasor's proportionate share of liability, at least under the current definition of "good faith". See Stambaugh v. Superior Court, 62 Cal. App. 3d 231, 238, 132 Cal. Rptr. 843, 847-48 (1st Dist. 1976). See also notes 78-81 infra and accompanying text.

20. Because of the potential burden on the judicial process from endless litigation as to the "good faith" of settlements, and given the adverse impact on the incentive to settle if settlements were frequently found, after the fact, to have been entered into in bad faith, courts are understandably reluctant to conduct an aggressive review of a settlement. For an indication of the judicial view of such challenges, see the cases cited in note 19 supra.

21. The authors of the 1955 version of the Uniform Contribution Among Tortfeasors Act indicated that attempts to prevent discrimination by plaintiffs were of doubtful effectiveness. The remedy under discussion there was the rule, present in the 1939 version of the Act, reducing a plaintiff's judgment by the pro rata share of liability attributable to the settled tortfeasor. Although the 1955 version put forward the alternative of the "good faith" requirement, the drafters' discussion of the problem leaves little room for confidence that a "good faith" requirement can prevent collusion or discrimination by the plaintiff. See Uniform Contrubutron Amono Tortfeasors AcT $\$ 4$, Comment (1955). For illustrations of situations where plaintiffs may be inclined to enter into low settlements, see notes 78-81 infra and accompanying text.

22. Compare the policies used to justify joint and several liability, which are discussed in notes 8-9 supra and accompanying text.

23. California courts have repeatedly stressed that settlements and compromises are favored by the law. See, e.g., Ash v. Mortensen, 24 Cal. 2d 654, 658, 150 P.2d 876, 878 (1944); Thomas v. General Motors Corp., 13 Cal. App. 3d 81, 86, 91 Cal. Rptr. 301, 304 (4th Dist. 1970). 
II

\section{Comparative Negligence AND}

\section{APPORTIONMENT OF LIABILITY}

The facts of the $L i$ case were quite simple. Plaintiff sued to recover damages for injuries suffered when her automobile was struck by a taxicab driven by an employee of the defendant. The trial court found that the taxi had been traveling at an unsafe speed, but barred the plaintiff from recovering because she had made a negligent turn into the path of the oncoming vehicle. ${ }^{24}$ The California Supreme Court reversed, rejecting the "all-or-nothing" rule of contributory negligence in favor of the doctrine of comparative negligence. ${ }^{25}$ The court's shift was notivated by two factors. First, the opimion recognized that, despite imstructions to the contrary, juries had frequently practiced a form of comparative negligence in their deliberations. ${ }^{26}$ The court felt that continued "jury lawlessness" could underinime public confidence in the integrity of the judicial process. ${ }^{2 \pi}$ More fundamentally, the court was convinced that both "logic and fairness" required that, in a system in which hability is based on fault, the extent of fault should govern the extent of liability. ${ }^{28}$

The $L i$ court did not directly address the problems of contribution and settlement in multiple party situations. It noted, however, that such problems "lurk in the background" and directed the lower courts to apply $L i$ 's rationale to unsettled areas of the law in a practical manner. ${ }^{29}$ Commentators were quick to read the $L i$ decision as encouraging judicial or statutory adoption of a system of comparative fault in the law governing the hability of jomt tortfeasors. ${ }^{30}$ The courts have been less certain of their mandate. Since the $L i$ decision, lower appellate courts have been presented with opportunities to extend $L i$ 's principle of comparative negligence to abrogate the doctrine of pro rata

24. 13 Cal. 3d 804, 809, 532 P.2d 1226, 1229-30, 119 Cal. Rptr. 858, 861-62 (1975).

25. Under the doctrine of contributory negligence, a plaintiff who is partially at fault in causing the injury complained of is completely barred from recovery for losses. Under comparative negligence rules, the fault of the plaintiff is compared to the fault of the tortfeasors and recovery is reduced in proportion to the plaintiff's share of the overall fault of the parties. For discussion of the different types of comparative negligence systems that have been adopted, see generally V. SchwarTZ, CoMPaRaTIVE NEGLIGENCE (1974).

26. 13 Cal. 3d at 811,532 P.2d at 1231, 119 Cal. Rptr. at 863 .

27. Id. at $811-12,532$ P.2d at 1231, 119 Cal. Rptr. at 863 .

28. Id. at $811,532 \mathrm{P} .2 \mathrm{~d}$ at $1231,119 \mathrm{Cal}$. Rptr. at 863 .

29. Id. at 823-27, 532 P.2d at 1240-42, 119 Cal. Rptr. at 872-74.

30. See commentators cited at note 3 supra. 
contribution among defendants, ${ }^{31}$ to allow a defendant to join unsued cotortfeasors, ${ }^{32}$ and to subject a settled tortfeasor to further liability in proportion to its fault. ${ }^{33}$ These cases show conflicting results, but they do suggest an outlime of settlement rules that are more in accord with Li.

In Safeway Stores $v$. Nest-Kart, ${ }^{34}$ both Safeway and Nest-Kart were defendants in the lower court. At trial, the jury found that plaintiff was not negligent, that Nest-Kart was $20 \%$ at fault for the plaintiff's injuries and that Safeway was $80 \%$ at fault. ${ }^{35}$ The trial court, relying on sections 875 and 876 of the Code of Civil Procedure, required Nest-Kart to pay a full $50 \%$ pro rata share of the damage award. $^{36}$ On appeal, Nest-Kart argued that it sliould liave been required to pay only that portion of plaintiff's damages for which it was at fault. The court of appeal affirmed, however, ruling that the clear language of the statute required the retention of pro rata apportionment, and that $L i$ had not overridden the clearly expressed intent of the legislature. ${ }^{37}$ The court noted, though, that Nest-Kart had not raised the question of whether the $L i$ decision abrogated the judicially created doctrine of joint and several liability. ${ }^{38}$

This fundamental question was decided two months later in American Motorcycle Association v. Superior Court. ${ }^{30}$ Defendant Association attempted to join as defendants the parents of the minor plaimtiff. The Association contended that the parents had been at fault in causing their son's injuries because they lad allowed him to participate in the motorcycle race sponsored by the Association when they knew of his lack of skill and traming. ${ }^{40}$ The trial court denied the motion on the ground that the common law granted the Association no cause of action against the parents. ${ }^{41}$ The court of appeal reversed,

31. E.g., Safeway Stores, Inc. v. Nest-Kart, 63 Cal. App. 3d 934, 134 Cal. Rptr. 150 (1st Dist. 1976), hearing granted, No. S.F. 23596 (Cal. Sup. Ct. Feb. 11, 1977) discussed at notes 34-38 infra and accompanying text.

32. E.g., American Motorcycle Ass'n v. Superior Court, 65 Cal. App. 3d 694, 135 Cal. Rptr. 497 (2d Dist. 1977), hearing granted, No. L.A. 30737 (Cal. Sup. Ct. Feb. 11,1977 ) discussed at notes 39-63 infra and accompanying text.

33. E.g., Stambaugh v. Superior Court, 62 Cal. App. 3d 231, 132 Cal. Rptr. 843 (1st Dist. 1976).

34. 63 Cal. App. 3d 934, 134 Cal. Rptr. 150 (1st Dist. 1976), hearing granted, No. S.F. 23596 (Cal. Sup. Ct. Feb. 11, 1977).

35. Id. at 936, $134 \mathrm{Cal}$. Rptr. at 151 .

36. Id. Cal. CTv. Proc. Code $\S \S 875$ and 876 appear in notes 13 and 14 supra.

37. 63 Cal. App. 3d at 936-39, 134 Cal. Rptr. at 151-53.

38. Id. at $937,134 \mathrm{Cal}$. Rptr. at 152 .

39. 65 Cal. App. 3d 694, 135 Cal. Rptr. 497 (2d Dist. 1977), hearing granted, No. L.A. 30737 (Cal. Sup. Ct. Feb. 11, 1977).

40. Id. at 698-99, 135 Cal. Rptr. at 499-500.

41. Because case law prior to American Motorcycle had imposed joint and several 
holding that the language and rationale of $L i$ required the abrogation of joint and several liability for concurrent tortfeasors. ${ }^{42}$ The court argued that joint and several liability traditionally rested, first, on an excessively formalistic "all-or-nothing" allocation of full liability to each person whose negligence contributed to the plaintiff's injury, without regard for the proportion of damages caused by the conduct of others, and second, on the theory that the totally innocent plaintiff is morally entitled to rely on all guilty defendants. ${ }^{43}$ The first argument, the court concluded, had been undercut by $L i$ 's reasoning that the extent of fault should determine the extent of liability. As to the second argument, the equities in favor of the plaintiff were substantially weakened where, as in this case, a plaintiff who previously would have been barred by contributory negligence might be permitted at least a partial recovery. ${ }^{44}$

Absent these justifications, the court argued, retention of joint and several liability operated only to shift the risk of insolvent tortfeasors from plaintiffs to defendants, ${ }^{45}$ and thus indirectly to society, a shift entailing high administrative costs. ${ }^{46}$ Since the adoption of comparative negligence had already shifted a cost to society that previously was borne solely by the negligent plaintiff, the general "societal fund"

liability on concurrent tortfeasors for the full amount of a plaintiff's damages, courts had held that defendants suffered no additional loss by not having other tortfeasors joined in the action and thus had no cause of action under which to cross-complain against unsued cotortfeasors. See Thornton v. Luce, 209 Cal. App. 2d 542, 551-52, 26 Cal. Rptr. 393, 399 (2d Dist. 1962).

42. 65 Cal. App. 3d at 700, 704, 135 Cal. Rptr. at 500, 503.

Concurrent tortfeasors are those whose independent acts contribute to the plaintiff's injury. Although the term "joint tortfeasors" is sometimes used narrowly to refer only to those who act in concert to cause the plaintiff's injury, the term is often used loosely enough to encompass those who have acted independently. See generally Prosser, supra note 8, at 291-99. In choosing to limit its discussion to concurrent tortfeasors, American Motorcycle was explicitly deferring on the question of how to handle the impact of $L i$ upon joint tortfeasors acting in concert or upon vicarious liability. $65 \mathrm{Cal}$. App. 3d at 697 n.1, 135 Cal. Rptr. at 499 n.1. Although this Comment will likewise not address these collateral issues, the more familiar term "joint tortfeasors" will be used hereafter rather than the more specialized term chosen by American Motorcycle.

43. 65 Cal. App. 3d at 700, 135 Cal. Rptr. at 501.

44. Id. at 700-01, $135 \mathrm{Cal}$. Rptr. at 501.

45. In discussing the effect of joint and several liability, the court spoke only of its inpact in shifting the burden of the insolvent tortfeasor. The court's failure to discuss the operation of the rule when unknown or absent tortfeasors are involved, or when settlements have been negotiated, may simply have been an oversight or may indicate that the court felt the insolvency problem was the only valid justification for joint and several liability. This omission in the court's analysis is discussed further at note 60 infra.

46. The court indicated that, because of "an ingrained system of contingent fees, claims administration costs, and expense incident to a complex procedure of litigation, somewhere between $\$ 2$ and $\$ 3$ of cost must be socialized to cover $\$ 1$ of loss shifted from the individual." 65 Cal. App. 3d at 702, 135 Cal. Rptr. at 502. 
should not also be burdened by the additional administrative cost associated with transfer of the risk of insolvent tortfeasors. ${ }^{47}$ In order to leave the burden of insolvency with the plaintiff, the court held that concurrent tortfeasors should no longer be subjected to joint and several liability for the entire damages of a contributorily negligent plaintiff. Instead, a concurrent tortfeasor should be liable only in proportion to fault. ${ }^{48}$ The court chose, however, to linit this holding to situations where the plaintiff was personally at fault. ${ }^{40}$ In order to bring into court all persons whose negligence contributed to the plaintiff's injury, the court granted the Association's request to join the unsued tortfeasors. $^{50}$ Shortly after the American Motorcycle decision, the California Supreme Court granted petitions for hearing in both American Motorcycle and Safeway, thus vacating both decisions. ${ }^{51}$

The solution proposed in American Motorcycle would have a sweeping impact on the rules of contribution and joinder. By allocating liability among defendants based upon their respective degrees of negligence rather than imposing it in solido, American Motorcycle dispatched the pro rata contribution rule which applies only where liability is joint and several. ${ }^{52}$ The decision's impact on the prior prohibition of joinder of tortfeasors by defendants is less clear. The opinion directed the trial court to grant the Association's motion for leave to file a cross-complaint against the plaintiff's parents. ${ }^{53}$ This action was justified by the "patent interest in having all persons whose fault con-

47. Id. at 703, 135 Cal. Rptr. at 502 .

48. "Where the $L i$ rule applies, liability among concurrent tortfeasors must be apportioned according to their respective degrees of negligence with each liable to the plaintiff only for his proportion." Id. at 704, 135 Cal. Rptr. at 503.

49. Id.

50. Id. at 707, 135 Cal. Rptr. at 505.

The issue of joinder of cotortfeasors is not new. Commentators have frequently argued that defendants should have the right to join cotortfeasors. See, e.g., Braun, supra note 3. The 1939 Uniform Contribution Among Tortfeasors Act proposed a rather elaborate procedural process for joining such torffeasors. UNIFORM CoNTRIBUTION AMONG TORTFEASORS ACT $\S 1$ and Comment (1939). The 1955 version of the Act, while rejecting the earlier Act's proposal for handling settlements, was in basic agreement with the idea that defendants were entitled to seek contribution from tortfeasors who had not been sued by the plaintiff. UNiform Contrinution AMONG TORTFEASORS ACT $§ 1$ (1955).

51. American Motorcycle Ass'n v. Superior Court, 65 Cal. App. 3d 694, 135 Cal. Rptr. 497 (2d Dist. 1977), hearing granted, No. L.A. 30737 (Cal. Sup. Ct. Feb. 11, 1977); Safeway Stores, Inc. v. Nest-Kart, 63 Cal. App. 3d 934, 134 Cal. Rptr. 150 (1st Dist. 1976), hearing granted, No. S.F. 23596 (Cal. Sup. Ct. Feb. 11, 1977).

52. The pro rata rule is contained in Cal. CIv. Proc. Code $\$ \$ 875-76$ (West Supp. 1977). See notes 13-14 supra and accompanying text. These statutes were designed to be applied only where tortfeasors were determined to be jointly and severally liable for the plaintiff's entire damages. See note 86 infra.

53. 65 Cal. App. 3d at 707, 135 Cal. Rptr. at 505. 
tributed to the injury before the court in one action." 54 If, however, a defendant is truly to be "liable to the plaintiff only for his proportion" of negligence, that liability will not be altered by the presence or absence of cotortfeasors, and the defendant would no longer be concerned about joining such tortfeasors. ${ }^{55}$ In that event, the "patent interest in having all persons . . . before the court" would presumably be the judicial interest in avoiding multiple litigation or the plaintiff's interest in avoiding the adverse consequences of the doctrine of collateral estoppel. ${ }^{56}$ On the other hand, if American Motorcycle is read narrowly so as to protect the defendant only from the liability attributable to insolvent tortfeasors, then the court's decision to permit joinder relieves defendants of the burdens associated with unsued tortfeasors and is essential to the goal of limiting each defendant's liability to that defendant's own proportion of fault.

It is difficult to deny that a systenn which allows joinder of unsued tortfeasors and allocates liability among tortfeasors in proportion to fault will accord inore closely with the principles announced in $L i$ than does the current system. Serious probleins arise, however, from American Motorcycle's decision to impose the entire burden of insolvent tortfeasors on the negligent plaintiff, regardless of the plaintiff's degree of fault. This solution allows the liability of both plaintiff and defendants to vary dramatically depending upon whether the plaintiff is found to be imnocent rather than minimally at fault. ${ }^{57}$ Such variations more closely resemble the all-or-nothing rules rejected in $L i$ than a system of liability in proportion to fault. By contrast, an

54. Id. at 706, 135 Cal. Rptr. at 504.

55. Although a defendant would still be interested in calling other tortfeasors as witnesses and persuading the jury that these tortfeasors were the truly culpable parties, a defendant held liable only for his own proportion of liability would have little need to join such tortfeasors, since the defendant would not be seeking contribution from such tortfeasors. See notes 16-17 supra and accompanying text.

56. To illustrate the possible impact of collateral estoppel, suppose $P$ wishes to recover for damages suffered due to the conduct of tortfeasors $A$ and $B$. Suppose further that $P$ sues $A$ alone and the jury determines that $A$ was $30 \%$ at fault and $B$ was $70 \%$ at fault in causing $P$ 's injury. Due process would seem to require that $B$ be allowed to establish nonliability should $P$ choose to sue the tortfeasors separately. It would thus be possible for the second jury to find $B$ free from fault, limiting $P$ 's total recovery to the $30 \%$ received from $A$. On the other hand, if the first jury determined that $A$ was $80 \%$ at fault, $B$ might be able to collaterally estop $P$ in subsequent litigation from claiming more than $20 \%$ of the damages from $B$. $P$ would thus be inclined to sue both $A$ and $B$ together to prevent this "no-win" result.

57. To illustrate, suppose $P$ is injured by tortfeasors $A$ and $B$, that $P$ suffers $\$ 10,000$ damages, and that $A$ is insolvent. Under American Motorcycle's proposed solution, if $P$ is found to be imnocent, $P$ will be able to collect $\$ 10,000$ from tortfeasor $B$. If, however, $P$ is found to be $5 \%$ at fault and $B$ is found to be $45 \%$ at fault (with the insolvent tortfeasor $50 \%$ at fault), $P$ will recover only $\$ 4,500$ from $B$ and will be forced to absorb both $P$ 's own share of fault aud $A$ 's share of fault. 
alternate solution, long advocated by commentators, would apportion this special burden aunong all parties, including plaintiffs, in proportion to their fault in causing the plaintiff's injuries. ${ }^{58}$ Where the plaintiff is not at fault, the burden of insolvency would continue to be borne solely by the solvent wrongdoers. Where the plaintiff is at fault, he would absorb his share of the insolvency burden just as would every other wrongdoer. This solution would eliminate the sharp fluctuations in liability caused by incremental changes in the position of plaintiffs, ${ }^{58}$ just as $L i$ eliminated the sharp distinction between innocent plaintiffs and negligent plaintiffs. This approach to the problem of insolvent tortfeasors would also provide a ineans of solving the problems caused by absent or unknown tortfeasors, problems not easily inanaged under American Motorcycle's approach. ${ }^{60}$

Although the court's analysis recognized that a logical extension of $L i$ required a "drastic revision of the principles governing liability of concurrent tortfeasors,"61 its holding was limited to those situations where plaintiffs were contributorily negligent. ${ }^{62}$ The narrowness of the holding inay have reflected a desire to limit it to the facts before the court. More likely, the court was forced to limit itself because of its decision to put the entire burden of insolvent tortfeasors on plaintiffs, a result justified by the court's rationale only where plaintiffs were contributorily negligent. ${ }^{63}$ It is clear, however, that $L i$ 's principle of liability in relation to fault applies fully whether the plaintiff is innocent or at fault. Given the recognized capacity of juries to apportion damages and the stated goal in $L i$ of logical and equitable treatment of parties, the scope of American Motorcycle's proposed reforms should extend to all concurrent tortfeasors, regardless of the status of any particular plaintiff.

58. See C. Gregory, Legislative Loss Distribution in Negligence Actions 78 (1936); G. Williams, Joint Torts and Contributory Negligence 416 (1951); Fleming, supra note 2, at 257-58.

59. Application of this system to the illustration at note 57 supra would mean that $\mathrm{P}, 5 \%$ at fault, would absorb $10 \%$ of the liability attributable to the insolvent tortfeasor, and $B$, who was $45 \%$ at fault, would absorb $90 \%$ of the insolvent tortfeasor's burden.

60. Where a plaintiff was unaware of the identity of one of the tortfeasors (as, for example, with a hit-and-run driver), judicial reluctance to allow a defendant to gain from the resulting uncertainty as to causation and relative fault, and judicial concern about assisting plaintiffs to receive at least a partial recovery, might argue against American Motorcycle's example of shifting such losses wholly onto the plaintiff. Compare Summers v. Tice, 33 Cal. 2d 80, 199 P.2d 1 (1948).

61. 65 Cal. App. 3d at 700, 135 Cal. Rptr. at 500.

62. Id. at 704, 135 Cal. Rptr. at 503.

63. The court in American Motorcycle rested its result on the ground that the only plaintiffs to be burdened were those who would not have been able to collect anything prior to $L i$ because of their contributory negligence. Id. at 703, 135 Cal. Rptr. at 502. Where plaintiffs are not contributorily negligent, this rationale breaks down, 


\section{III}

\section{Comparative Liability and Settlements}

Although the decision in American Motorcycle did not address the problem of settlements, it is clear that its rationale, if extended, would require changes in settlement law. The current pro tanto rule reduces the judgment against defendants by the dollar amount of the settlement, thus permitting the defendants' liability to fluctuate in proportion to the amount of the settlement rather than the relative degree of fault of the defendants. ${ }^{64}$ If the plaintiff settles in good faith with one tortfeasor and the jury subsequently finds that the settled tortfeasor was responsible for a much larger portion of the plaintiff's damages, the defendant who at great cost has successfully demonstrated a relative lack of fault will nonetheless be compelled to pay more than his proportionate share of damages.

At a minimum, consistency with the theory of $L i$ and American Motorcycle requires that, when the plaintiff has settled with one or more joimt tortfeasors, a subsequent judgment against cotortfeasors should be reduced by the proportion of the plaintiff's damages attributable to the fault of the settled tortfeasor. Under such a proportionate reduction rule, the defendants would be protected from the fluctuations in liability that now result under the pro tanto rule, thus furthering the central principle of $L i$ and American Motorcycle. ${ }^{.5}$

64. To illustrate this fluctuation, suppose $P$ is injured by two tortfeasors, both equally at fault. If $P$ suffers damages of $\$ 10,000$, a system in which the extent of fault governed the extent of liability would presumably hold each tortfeasor liable for $\$ 5,000$. If, however, $P$ settles with tortfeasor $A$ for $\$ 3,000$ and sues tortfeasor $B$, application of the pro tanto reduction rule would subject tortfeasor $B$ to liability for the remaining $\$ 7,000$. Conversely, if $P$ had settled with tortfeasor $A$ for $\$ 6,000$, tortfeasor $B$ 's liability would only have been $\$ 4,000$, although the relative fault of the parties would not have changed. Only in the situation where the parties to the settlement were able to accurately predict the jury verdict of $\$ 10,000$, and settle accordingly for $\$ 5,000$, would the defendant's liability be apportioned in relation to fault.

65. The National Conference of Commissioners on Uniform State Laws has adopted a proposal of this type in its new Uniform Comparative Fault Act. The Act, adopted on August 4, 1977, provides in part:

(2) (a) In all actions involving fault of more than one party to the action, including third-party defendants and persons who have been released under Section 6 , the court, unless otherwise agreed by all parties, shall instruct the jury to answer special interrogatories or, if there is no jury, shall make findings, indicating:

(1) the amount of damages each claimant would be entitled to recover if contributory fault is disregarded; and

(2) the percentage of the total fault of all of the parties to each claim that is allocated to each claimant, defendant, third-party defendant, and person who has been released from liability under Section 6 . For this purpose the court may determine that two or more persons are to be treated as a single party.

(b) In determining the percentages of fault, the trier of fact shall con- 
Although this change in the pro tanto rule may be desirable, in that it adheres to the policy of liability in proportion to fault and in terms of fairness to defendants, it could provide a disincentive to those contemplating settlement. Certainly, the elimination of joint and several liability proposed by American Motorcycle will have a significant impact on settlements since it will reduce much of the settlement leverage currently exercised by plaintiffs. ${ }^{\circ 6}$ If these proposed changes have an overall adverse impact on settlements, the strong policy in favor of settlements may present an obstacle to adoption of these reforms. ${ }^{67}$ Thus, before American Motorcycle can be extended to situations involving settlements and before the pro tanto rule can be replaced by a proportional reduction rule, the effect of the proposed reforms on the operation of settlements must be examined.

sider both the nature of the conduct of the person and the extent of the causal relation between the conduct and the damages claimed.

(c) The court shall determine the award of damages to each claimant, subject to any reduction under Section 6 , in accordance with the findings and enter judgment against each party liable on the basis of rules of joint-andseveral liability. ... [T]he court also shall determine and state in the judgment each party's equitable share of the obligation to each claimant in accordance with their respective percentages of fault.

(d) Upon motion made before or within [one year] after judgment is entered, the court shall determine whether all or part of a party's equitable share of the obligation is uncollectible from that party, and shall reallocate any uncollectible amount among the other parties, including a claimant at fault, according to their respective percentages of fault. The party whose liability is reallocated is nonetheless subject to contribution, and to any continuing liability to the claimant on the judgment.

(6) A release, covenant not to sue or similar agreement entered into by a clainant and a person liable discharges that person from all liability for contribution, but does not discharge any other persons liable for the same damage unless it so provides. However, the claim of the releasing person against other persons is reduced by the amount of the released person's equitable share of the obligation, determined in accordance with the provisions of Section 2.

Reprinted in Kroll, Comparative Fault: A New Generation in Products Liability, 1977 INS. L.I. 492, at n.1. This draft is subject to minor modification by the Committee on Style of the National Conference.

The California State Bar Standing Committee on Administration of Justice has recently recoinmended some reforms to the Board of Governors that would alter the California contribution statutes so as to reduce the plaintiff's judgment by the largest of the following: (1) the amount stipulated by the release, the dismissal, or the covenant; (2) the amount of the consideration paid for it; or (3) the amount of the released tortfeasor's equitable share of the damages. State Bar Standing Committee on Administration of Justice, Proposed Statute Re Comparative Negligence and Contribution, Section 10 (August 1977) (on file at the California Law Review). For a discussion of the possible disincentives to settlements that could result from reducing plaintiff's recovery by the greatest of these amounts, rather than solely by the amount of the released tortfeasor's equitable share of the damages, see notes 71-77 infra and accompanying text.

66. By threatening to sue only one of several tortfeasors and thereby to hold only that person liable for the plaintiff's entire damages, plaintiffs currently can exercise a great deal of settlement leverage. For a discussion of some of the abuses of this power, see Comment, Settlement in Joint Tort Cases, supra note 10.

67. See note 23 supra and accompanying text. 
When the settling parties have correctly estimated the amount of liability attributable to a settled tortfeasor, the pro tanto rule reaches the same result as a proportional reduction rule. ${ }^{.8}$ Therefore, inquiry can be limited to situations where the settlement is higher or lower than the settled tortfeasor's share of liability, whether because of unintentional errors of fact or judgment or, as in the case of settlements with friendly or insolvent torifeasors, by choice.

\section{A. Unintentionally low settlements}

A plaintiff who unintentionally underestimates the amount of dainages, or the share of fault that the jury will assign to the settled tortfeasor, will receive less compensation from the defendants under a proportional reduction rule than under the pro tanto rule. To illustrate, suppose $P$ is injured by two tortfeasors, $A$ and $B$. If $P$ and $A$ believe in good faith that $P$ has suffered $\$ 10,000$ damages and that $A$ is forty percent at fault, they should settle for $\$ 4,000$. Suppose, however, that the jury subsequently determines that $A$ is seventy percent at fault and $B$ only thirty percent at fault in causing $P$ 's injury. Under the pro tanto rule, $P$ will still receive $\$ 6,000$ from $B$ ( $\$ 10,000$ verdict less the $\$ 4,000$ settlement) regardless of his mistake. Under a proportional reduction rule, $P$ would receive only $\$ 3,000$ from $B$, since $B$ would receive credit for the $\$ 7,000$ liability attributed by the jury to tortfeasor $A$.

To allow plaimtiff to recover the $\$ 3,000$ difference froin the settled tortfeasor would eliminate any incentive for such tortfeasors to settle, vitiating the strong policy in favor of settlements. ${ }^{69}$ To leave the burden with the plaimtiff could also have a discouraging inpact on settlements. Several factors should, however, offset this disincentive. First, a settlement guarantees the plamtiff at least a partial recovery and cushions the risk of loss resulting from an unfavorable judgment in subsequent litigation. Second, a settlement may provide the plaintiff with compensation at a time when money is desperately needed to ineet expenses arising from the injury. Finally, if the plaintiff is allowed to keep the benefits of a favorable settlement, the possibility of gam inay help counterbalance the risk of loss from an unfavorable low settlement. ${ }^{70}$

\section{B. Unintentionally High Settlements}

Situations will arise where parties to the settlement agreement apparently overestimated the share of liability attributable to the settled

68. See illustration at note 64 supra.

69. Stambaugh v. Superior Court, 62 Cal. App. 3d 231, 236, 132 Cal. Rptr. 843, 846 (1st Dist. 1976).

70. See notes 71-73 infra and accompanying text. 
tortfeasor. Where the overestimation is illusory because the jury has returned a low verdict, the current pro tanto rule doubly penalizes the plaintiff, since an already low verdict is further diminished by an excessive reduction for the settlement. Assunie, for example, a situation where tortfeasors $A$ and $B$ are, respectively, forty percent and sixty percent responsible for damages to $P$ in the amount of $\$ 15,000$. Correctly estimating $A$ 's share of liability, $P$ settles his claim agaimst $A$ for $\$ 6,000$. Subsequently, the jury returns a verdict establishing $P$ 's total damages at $\$ 10,000$. Under the pro tanto reduction rule, $P$ 's recovery from $B$ is reduced to $\$ 4,000$, and the total recovery is limited to $\$ 10,000$. Under the proportional reduction rule, $B$ would pay $\$ 6,000$, increasing $P$ 's total recovery to $\$ 12,000$ and thereby diminishing the impact of the jury's error.

Even where the jury verdict is accurate, and the plaintiff therefore gains a true windfall if allowed to retain the benefit of a high settlement, the symmetry of the risk-reward calculus that underlies the policy in favor of settlenients requires that the plaintiff be permitted to do so, despite the fact that such a windfall technically violates the doctrime of one satisfaction. ${ }^{71}$ To deny plaintiffs the benefit of favorable settlements while imposing on them the burden of low settlements would create a no-win situation which would sharply diminish the motivation to enter into settlements. ${ }^{72}$ By contrast, allowing retention of the benefits of a high settlement presents the multiple-tortfeasor plaintiff with a choice similar to that of the plaintiff injured by a single tortfeasor. In that setting, the possibility of gain from a high settlement, coupled with the certainty of an iminediate recovery, is weighed against the possibility of loss. Most such plaintiffs settle their claims, ${ }^{73}$ and there is no reason to anticipate a different result in the multiple-tortfeasor situation.

The fact that the windfall apparently violates the doctrine of one satisfaction does not weigh heavily against awarding the benefit of the settlement to the plaintiff. The rationale for the doctrine of one satisfaction is to prevent the plamtiff from unjustly enriching himself at the expense of the other parties. ${ }^{74}$ Where, however, no overreaching is

71. See note 11 supra and accompanying text.

72. To illustrate how plaintiffs might suffer, suppose $P$ is seeking to recover $\$ 10,000$ in damages caused by tortfeasors $A$ and $B$. If $P$ settles with $A$ based on an estimate that $A$ was $40 \%$ at fault, $P$ will lose $\$ 1,000$ under the proportional reduction rule if the jury determines that $A$ was actually $50 \%$ at fault. If a jury decides that $A$ was only $30 \%$ at fault and if $P$ is forced to return $\$ 1,000$ of the settlement to $A, P$ will run a risk of loss by settling, with no offsetting possibility of gain from a favorable settlement.

73. See note 5 supra.

74. See Theobald v. Angelos, 44 N.J. 228, 239, 208 A.2d 129, 135 (1965). 
involved, courts have held that the doctrine is not violated. ${ }^{75}$ In such cases technical violation of the doctrine is compelled by the strong public policy in favor of settlements, and no objection on the ground of unfairness can be sustained.

The arguinent supporting the one satisfaction doctrine would have greater impact if either the defendant or the settled tortfeasor had a strong equitable clain to the benefits of the high settlement. ${ }^{76}$ The clains of both, however, are weak. Defendants have been required under the proportional reduction rule to pay only their own share of liability, and they have not contributed anything to the settlement excess. Since they are protected by the proportional reduction rule from the burden of a low settlement, they cannot clain that they are entitled to the offsetting benefits of the rule. Indeed, to award defendants a windfall from such settlements could discourage some tortfeasors from settling in the hopes of gaining, as defendants, the benefits of the settlements of their cotortfeasors. ${ }^{77}$

The settled tortfeasor's claim to the benefits of a high settlement is also weak. Certainly such a tortfeasor has no equitable claim. The settled tortfeasor has contracted with the plaintiff to limit liability and "buy his peace." In return, the tortfeasor can fairly be said to have contracted away the right to any benefits resulting from a deterinination that the settlement was "high." When this meager or nonexistent interest is weighed against the potentially harmful impact on settleinents from denying the benefits to the plaintiff, the conclusion is inescapable that the settled tortfeasor's claim should be denied.

75. Id. at 238,208 A.2d at 134 .

76. For example, although Professor Glanville Williams argues strongly that the plaintiff in such situations should not receive more than one satisfaction, he has difficulty making a convincing argument that either the settled tortfeasor or the defendant should receive the benefit of the settlement. G. WILliaMs, supra note 58, at 152-55. For a more detailed discussion of the arguments in favor of awarding the benefits of a high settlement to the plaintiff in such circumstances, see Larson, A Problem in Contribution: The Tortfeasor with an Individual Defense Against the Injured Party, 1940 WIS. L. Rev. 467, 486-91 (1940).

77. New Jersey formerly had a contribution statute that required a judgment against defendants to be reduced by the pro rata share of liability attributable to settled cotortfeasors. N.J. STAT. ANN. \& 2A:53A-1 to -5 (West 1952). In Theobald v. Angelos, 44 N.J. 228, 208 A.2d 129 (1965), the New Jersey Supreme Court was faced with the question of who should receive the benefit when a settlement exceeded the pro rata share of liability of the settled tortfeasor. The court recognized that the doctrine of one satisfaction did not argue against giving such benefits to the plaintiff when there was no threat to the public interest or unfair advantage taken of another. By contrast, the court felt that the strong policy in favor of settleinents argued for giving these benefits to the plaintiff, both to encourage hiln to settle and to discourage defendants from litigating in hopes of gaining the benefits of the settlements of their cotortfeasors. Id. at $237-41,129$ A.2d at 134-36. While the dissent argued that the one satisfaction doctrine barred plaintiff's recovery of these benefits, the dissenting justices were split on who should receive them. Id. at 241-43, 129 A.2d at 136-37. 


\section{Intentionally Low Settlements}

Adoption of a proportional reduction rule would discourage plaintiffs from knowingly entering into low settlements. These intentional underestimations arise where the plaintiff desires to exclude some tortfeasors from the litigation or where the plaintiff encounters a partially insolvent tortfeasor.

In the first situation, the plaintiff may, for example, prefer to settle for a nommal amount with a tortfeasor who is a friend or relative. Similarly, the plaintiff may not wish to sue a tortfeasor who is popular in the community or may decide to trade a low settlement for favorable testimony. ${ }^{78}$ Under the pro tanto rule, plaintiffs were not discouraged from entering into such settlcments, since they could pass on any burden to a defendant held jointly and severally liable for the plaintiff's entire loss. ${ }^{79}$ Although such settlements are in violation of the "good faith" requirement, that requirement lias im practice proved to be difficult to enforce. ${ }^{80}$ A proportional reduction rule, by forcing the plaintiff to assume the loss resulting from the artificially low settlement, will discourage sucl1 settlements and may achieve the goals of the good faitl standard more effectively than does the pro tanto rule.

A more troublesome problem arises where plaintiffs are in immediate need of funds, perhaps to offset expenses resulting from their imjuries. Sucl plaintiffs are in a weakened bargaining position and may be pressured by a tortfeasor to settle for less than the tortfeasor's actual share of liability. To the extent that public policy favors aiding plaintiffs to recover in full for their injuries, it argues against adoption of a proportional reduction rule. It is not clear, lowever, how often plaintiffs are placed at sucl a severe disadvantage. There is certainly no evidence that it occurs more frequently in the multiple tortfeasor situation than with single tortfeasors. In any event, the problem is minimized in the multiple tortfeasor situation, since a plaintiff can negotiate with several tortfeasors to get the most advantageous immediate settlement.

A frequent cause of intentionally low settlements is the plaintiff's recognition of the limited financial resources of a tortfeasor. These situations are especially troublesome simce other parties will be re-

78. For a discussion of the situations in which plaintiffs intentionally enter into low settlements, see James, supra note 5 . With decreased intrafamily immunity and abrogation of the automobile guest statute, an increase in the number of cases in which a plaintiff could sue tortfeasors who are friends or relatives can be expected. See generally Brown v. Merlo, 8 Cal. 3d 855, 506 P.2d 212, 106 Cal. Rptr. 388 (1973); Self v. Self, 58 Cal. 2d 683, 376 P.2d 65, 26 Cal. Rptr. 97 (1962).

79. See illustration in text preceding note 69 supra.

80. See note 20 supra. 
quired to absorb a burden created by the partially insolvent tortfeasor. Although such circumstances require a special modification of the proposed proportional reduction rule, an approximation of $L i$ 's goal of "logic and fairness" can be achieved in conjunction with the adoption of the modification of American Motorcycle discussed above. ${ }^{81}$

\section{Intentionally High Settlements}

Because current rules impose joint and several liability and deny defendants the right to join unsued tortfeasors, plaintiffs liave tremendous bargaining leverage over individual tortfeasors, who run the risk of being held responsible for the entire liability attributable to several wrongdoers. ${ }^{82}$ Given this leverage, retention of the pro tanto rule or inodification of the proportional reduction rule might be justified so as to prevent a plaintiff from gaining a double recovery. With American Motorcycle's decision to apportion liability among defendants in relation to fault and to allow joimder of unsued tortfeasors, this last justification for the pro tanto rule disappears.

In summary, the proposed changes in the rules governing contribution and settlements should not be barred by the policy in favor of settlements. Tortfeasors will continue to be encouraged to settle by the rule protecting them from further liability and allowing them to buy their peace. Plaintiffs will, of course, be discouraged from entering into bad faith settlements. On the other hand, plaimtiffs will benefit from the proportional reduction rule in cases of low jury verdicts. Judging by the experience in Wisconsin, which has had a system of proportional hability among tortfeasors for a number of years, the risk of a low settlement and the loss of the leverage created by jomt and several liability should be offset by the opportunity for gain from a favorable settlement. ${ }^{83}$ To the extent that some dismcentive to settlement

81. See notes 58-60 supra and accompanying text. There are several procedural techniques whereby the proportional reduction rule can be implemented in situatious involving insolvent tortfeasors. Of course, if a tortfeasor is completely insolvent, the plaintiff will be uuable to extract anything in settlement and it will be irrelevant whether the plaintiff or the defendaut brings the tortfeasor into any litigation. If, however, a tortfeasor has some resources, but not enough to pay for his estimated share of liability, a settlement may be the simplest solution. If the exteut of the insolvency is recognized by both the plaintiff and the solvent tortfeasors, they can take it into account in their settlement negotiations. If there is disagreement and the remaining tortfeasors refuse to pay their additional shares, the plaintiff may be forced to seek a pretrial determination of the issue by the court. If settlement negotiations fail to prevent litigation, the court need only take the pretrial deterinination into account when apportiouing the jury verdict among the parties involved.

82. See note 66 supra and accompanyiug text.

83. The Wiscousin Supreme Court adopted a system of apportioning liability among tortfeasors in 1962. Bielski v. Schulze, 16 Wis. 2d 1, 114 N.W.2d 105 (1962). 
rennains, it should be outweighed by the more equitable treatment accorded tortfeasors under these changes.

\section{IV}

\section{Adoption of Proportional Liability}

The chief obstacle to replacement of the pro rata contribution rule with a proportional contribution rule and replacement of the pro tanto rule with a proportional reduction rule is the California Contribution Act. ${ }^{84}$ At least one California Court of Appeal has held that this statutory provision bars judicial extension of $L i$ to the problem area of liability among tortfeasors. ${ }^{85}$ The legislative history of the Contribution Act, however, clearly shows that the Act is only to be applied in those situations where tortfeasors are held jointly and severally liable for the plaintiff's entire damages. ${ }^{80}$ Since joint and several liability is essentially a cominon law doctrine, ${ }^{87}$ it follows that the proportional contribution rule and the proportional reduction rule can be adopted by judicial action without hindrance by the Contribution Act. ${ }^{88}$ Furthermore,

Practioners have noted that this system, by apportioning liability in relation to fault rather than according to fixed pro rata shares, tends to encourage parties to settle their disputes, since there is less likelihood of sharp swings in liability because of small changes in a jury's findings and therefore less to gain froin litigation. See C. HeFT \& J. Heft, Comparative Negligence Manual $\$ \S 4.200-.220$ (1971).

84. Cal. Civ. Proc. Code $\S \S 875-77$ (West Supp. 1977), discussed in notes 13 16 supra and accompanying text.

85. See notes 34-38 supra and accoinpanying text.

86. Section 877 was evidently modeled after $\S 1$ of the 1955 Uniform Contribution Ainong Tortfeasors Act and intended to apply to "joint tortfeasors." See River Garden Farms, Inc. v. Superior Court, 26 Cal. App. 3d 986, 996, 103 Cal. Rptr. 498, 505 (3d Dist. 1972); 1 Cal. J. of the Senate Appendx 129 (Reg. Sess. 1957). While the 1955 Act did not define "joint tortfeasors", it essentially adopted the 1939 Act's definition of "two or more persons jointly or severally liable in tort for the same injury." See UNIForm ConTribution AMONg ToRTfEAsors ACT $\S 1$ (1939); $\S 1$ and Comment (1955).

87. American Motorcycle Ass'n v. Superior Court, 65 Cal. App. 3d 694, 705, 135 Cal. Rptr. 497, 504 (2d Dist. 1977), hearing granted, No. L.A. 30737 (Cal. Sup. Ct. Feb. 11, 1977).

88. In addition to elimination of joint and several liability, there are special arguments that would support a finding that $\S 877$ in particular is no obstacle to judicial action. Although $\S 877$ departed from the California cominon law in abrogating the rule that a release of one tortfeasor released all tortfensors, the adoption of the pro tanto rule was essentially a codification of existing common law. See Selected 1957 Code Legislation, 32 CAL. ST. B.J. 501, 554-55 (1957). This fact suggests that $\$ 877$ presents no bar to adoption of a proportional reduction rule.

$L i$ v. Yellow $C a b$ established the broad proposition that legislative action that constitutes a codification of the common law does not prevent judicial action that advances the purposes underlying the legislative action. $13 \mathrm{Cal}$. $3 \mathrm{~d}$ at $821-22,532$ P.2d at $1238-39,119 \mathrm{Cal}$. Rptr. at 870-71. The legislative goals in adopting the 1957 Contribution Act (CaL. Crv. Proc. Code $\$ \$ 875-80$ (West Supp. 1977)) were to achieve equitable sharing of costs among the parties at fault while encouraging settlements. 
it has long been recognized that, when a "basis can be found for some rough practical apportionment, which limits a defendant's liability to that part of the harm which he has in fact caused, it may be expected that the division will be made."89 The innovative approach of $L i$ and the recognition of the ability of juries to apportion liability among the parties provide a basis for apportioning liability among tortfeasors in proportion to their fault, allowing abrogation of the doctrine of joint and several hability where necessary to adopt the desired reforms.

While judicial action $m$ this area is possible, courts may be hesitant to undertake the necessary statutory reinterpretations without a strong showing that judicial action is the preferable method of adopting the proposed reforms. In analyzing $L i$ 's adoption of comparative negligence, Professor Fleming has suggested three criteria that are relevant to the question of which branch is better suited to altering the rules governing liability among joint tortfeasors: (1) which body is better equipped to understand the nature and implications of the problems and to make an inforned choice froin available alternatives; (2)

River Garden Farms, Inc. v. Superior Court, 26 Cal. App. 3d 986, 103 Cal. Rptr. 498 (3d Dist. 1972); 1 Cal. J. of the Senate Appendix 130 (Reg. Sess. 1957). As this Comment has shown, adoption of a proportional reduction rule would achieve a more equitable sharing of costs without discouraging parties from settling. Thus, Li's rationale would provide a basis for arguing that the legislature did not intend for $\S 877$ to block adoption of a proportional reduction rule.

There is, of course, a considerable difference between the codification action undertaken in 1872 and the codifying nature of the 1957 action. Extension of $L i$ 's analysis would certainly stretch the notion of "liberal construction." Closer analysis of the action taken in $L i$, however, indicates that reinterpretation of the 1957 Contribution Act might not be much more liberal than the interpretation conducted in $\mathrm{Li}$. See Englard, $\mathrm{Li}$ v. Yellow Cab Co.-A Belated and Inglorious Centennial of the California Civil Code, 65 CaLif. L. Rev. 4, 22-27 (1977).

If it is determined that plaintiffs should be denied the benefits of high settlements, a modified form of the proportional reduction rule could be adopted by judicial redefinition of the "good faith" standard of CAI. Civ. Proc. CODE $\$ 877$ (West Supp. 1977). Good faith settlements should generally represent the plaintiff's estimation of the settled tortfeasor's proportionate share of liability. Courts could therefore find an implied covenant in every settlement agreement stipulating that the settlement was intended to reduce the plaintiff's claim in proportion to the settled tortfeasor's share of liability. Any settlement agreement that contained an express covenant to the contrary would be deemed to be in bad faith and be disregarded. As with most such statutes, $\$ 877$ provides that any settlement shall reduce the claims against other tortfeasors by the amount stipulated in the settlement or by the amount of consideration paid for the settlement, whichever is greater. See note 16 supra. On the basis of the implied covenant, the benefit of high settlements would accrue to the defendants; in all other cases, the proportional reduction rule would operate normally.

While the proportional reduction rule could be adopted by independent judicial action, such piecemeal action could create the possibility of extortionate settlements if defendants were not also given the right to join unsued tortfeasors. See note 82 supra and accompanying text.

89. See Prosser, supra note 8, at 313-14. 
whether the reform can be adopted by a single judicial stroke or requires resolution of details and collateral issues more appropriate for legislative action; and (3) whether it is necessary to rely on legislative reform so as to give affected parties time to prepare themselves for the change of law. ${ }^{90}$

First, it is clear that courts are better equipped than legislatures to understand the problems involved in determining the ability of juries to apportion liability among tortfeasors, the good faith of parties to settlement agreements, the incentives and disincentives to settlement, and the inequities in allowing the distribution of liability to rest on the determination of plaintiffs. ${ }^{91}$ Second, the American Motorcycle case provides an opportunity to adopt the major reforms in one stroke. The California Supreme Court need only affirm American Motorcycle's adoption of proportionate liability among defendants, without retaining its dubious limitation to cases involving contributory negligence ${ }^{02}$ or its inequitable solution to the problem of insolvent tortfeasors. ${ }^{03}$ Such a decision would abrogate the doctrine of pro rata contribution and permit joinder of unsued tortfeasors. As for the pro tanto settlement rule, the $L i$ court dealt with issues of similar moment-assumption of risk and last clear chance-in dictum, ${ }^{04}$ and the same could be done here. The court could again leave to the trial courts the determination of procedural problems, such as when to allow jomder and when to sever actions. It is true that collateral issues remain to be resolved when intentional torts, vicarious liability, indemnity, or strict liability are involved. ${ }^{25}$ Courts developed these doctrimes, however, and should therefore be competent to adapt thein to the altered circumstances. By contrast, legislatures have generally proved mcapable of addressing

90. Fleming, supra note 2, at 279-81.

91. Trial courts have long been involved in the settlement process and have now, as a result of the $L i$ decision, been required to become involved in the process of apportioning liability between defendants and negligent plaintiffs. They have also had to address the problems of "good faith" settlements and joint and several liability on a continual basis. See cases cited at notes 9 and 19 supra. Compare Fleming, supra note 2, at 279 ("on the question of contributory negligence, one cannot very well dispute the unique judicial experience and preoccupation, after daily confrontation with it over more than a century and a record of continuing refiguration ....")

92. See notes 61-63 supra and accompanying text.

93. See notes 57-60 supra and accompanying text.

94. 13 Cal. 3d at 824-25, 532 P.2d at 1241-44, 119 Cal. Rptr. at 872-73.

95. Recognizing the difficulties involved, the court in American Motorcycle Ass'n $v$. Superior Court chose not to consider "the impact of the rule of $\mathrm{Li}$ upon joint tortfeasors acting in concert or upon vicarious liability." 65 Cal. App. 3d 694, 697 n.1, 135 Cal. Rptr. 497, 499 n.1. Analysis of these problems is beyond the scope of this Comment and may turn heavily on the practical difficulties in asking juries to handle such relationships. 
such issues in adopting comparative negligence statutes. ${ }^{96}$ Finally, there is little indication that legislative action is necessary to give affected parties some advance notice. The most significant of the changes proposed here affect the distribution of liability among tortfeasors; the imstances where a tortfeasor's insurer is required to pay more should be offset by instances where that same imsurer will be able to pay less on behalf of other clients. If American Motorcycle's solution to the problem of imsolvency is modified in the manner proposed above, ${ }^{97}$ the oscillation of liability between plaintiffs and defendants will be dampened. While the liability of individual plamtiffs and tortfeasors may vary, the liability imposed on groups of plamtiffs and tortfeasors should remain constant. It would thus appear that the advantages of judicial reform outweigh any hesitancy to reinterpret the contribution statutes. If, however, courts are reluctant to tamper with the scope of the Contribution Act, the necessary improvements in the treatment of tortfeasors must await legislative action.

\section{CONCLUSION}

Logical extension of $L i$ v. Yellow Cab's primciple of apportioning liability in relation to fault argues for adoption of proportional liability among tortfeasors. This reform mandates rejection of pro rata contribution among defendants and replacement of the pro tanto settlement rule with a rule that reduces judgments against defendants by the proportion of liability attributable to the settled tortfeasor. Taken together, these reforms should provide more logical and equitable treatment of tortfeasors. While these changes will significantly alter the operation of settlements, the resulting equilibrium should not find plaintiffs unreasonably discouraged from entering into settlement agreements. These changes can appropriately be accomplished by judicial modification to the doctrine of joint and several liability, and judicial expertise in this area argues agamst deferring to the legislature.

\section{David Kikel*}

96. Senate Bills 494 and 2119 were the only relevant bills introduced during the 1975-76 Regular Session of the California Legislature. Neither bill addresses any of these collateral problems. For a discussion of legislative attempts to address this problem see generally V. ScHWARTZ, supra note 25, at 34-36, 99-113, 195-209.

97. See note 58 supra and accompanying text. of Law,

* A.B., B.S. 1969, University of Kansas; third-year student, Boalt Hall School 